\title{
Evaluation of Diagnostic Value of Adenosine Deaminase in Diagnosis of Tuberculous Pleural Effusion
}

\author{
TALAAT A. MOHAMED, M.D.*; AHMED M. TAHOUN, M.D.**; MOUSTAFA A. ZEDAN, M.D.* and \\ MOHAMED S. MOHAMED, M.Sc.* \\ The Departments of Chest Disease* and Clinical Pathology**, Faculty of Medicine, Al-Azhar University
}

\begin{abstract}
Background: Many studies suggest that adenosine deaminase is a marker for tuberculous pleurisy, while controversy exists as to its diagnostic value, accurate diagnosis is essential for tuberculous effusion for initiation of treatment. So evaluation of diagnostic value of adenosine deaminase in diagnosis of tuberculous pleural effusion is important.
\end{abstract}

Aim of the Work: To evaluate the diagnostic value of adenosine deaminase in diagnosis of tuberculous pleural effusion from non tuberculous pleural effusion.

Subject and Methods: Forty patients with pleural effusion were admitted to Giza chest hospital, Bab El-Sha'eria and Al-Hussein Al- Azhar University Hospital and after taking a written informed consent from the patients during period between April 2014 and May 2016.

All patients were subjected to full history and clinical examination, Plain chest X-ray, Sputum examination for Acid Fast Bacilli, ADA in pleural fluid, pleural biopsy and Culture and sensitivity of pleural fluid. Those patients were classified into (2) groups: Group (I): Twenty (20) patients with tuberculous pleural effusion. Group (2): Twenty (20) patients without tuberculous pleural effusion.

Results: Patients with tuberculous pleural effusion had significantly high ADA level in pleural fluid than patients with non-tuberculus effusion (parapneuomonic and malignant effusion) with $p<0.001$ with cutoff point in pleural fluid was $68.8 \mathrm{IU} / 1$, sensitivity and specificity were $90 \%$ and Positive predictive value was $90 \%$.

Conclusion: Adenosine deaminase ADA can be used in diagnosis tuberculous pleural effusion with significantly increase ADA level in pleural fluid than those with malignant, parapneumonic effusion. So Adenosine Deaminase ADA is a non invasive, inexpensive and repeatable test provides the results quickly which help to start early treatment.

Key Words: ADA - Adenosine deaminase - Tuberculous effusion.

Correspondence to: Dr. Talaat A. Mohamed, The Department of Chest Disease, Faculty of Medicine, Al-Azhar University

\section{Introduction}

PLEURAL effusion is fluid in the pleural space and categorized as either transudate or exudate [1]

Tuberculous pleurisy one of extra-pulmonary tuberculosis [2]. Diagnosed by pleural tissue biopsy and pleural fluid examination. And the culture for mycobacterium in pleural fluid has a relative lower success rate $(36 \%)$ [3]. The diagnosis is difficult in as many as $20 \%$ of cases [4]. And cutoff value of ADA is still to be studied [5].

Aim of the work: To evaluate the diagnostic value of adenosine deaminase in etiological diagnosis of pleural effusion.

\section{Subjects and Methods}

This study was conducted on Giza chest hospital, Bab El-Sha'eria university Hospital and AlHussein University Hospital after recording written consent from the patients during period between April 2014 and May 2016 and includes 40 patients.

Forty patients classified into two groups:

Group (I) : (20) patients with tuberculous pleural effusion diagnosed clinical, radiological, bacteriological and also by pleural biopsy.

Group (2): (20) Patients with Non tuberculous pleural effusion diagnosed clinical, radiological, bacteriological and also pleural biopsy, and include 15 cases with malignant effusion and 5 cases with parapneumonic effusion.

\section{ALL patients underwent the following:}

History taking clinical examinations, plain chest X-ray, Sputum for AFB, Laboratory investigations ,Complete Blood Picture, kidney function, liver function, random blood sugar, Tuberculin 
skin test, ADA in pleural fluid, Histopathological examination (pleural biopsy either open or Abram's) and Culture of pleural fluid.

$50 \mathrm{~mL}$ of pleural fluid or more was collected in a syringe. Portion of the sample was taken for cytological examination, and measurement of protein, lactate dehydrogenase (LDH), and glucose, while the other portion for measurement ADA and early morning sputum sample from each patient on 3 successive days.

Closed pleural biopsy has been carried out for patients with tuberculosis and patients with malignancy by Abraham's or Coop's needle with a trocar and cannula at 3,6, 9 o'clock (but not 12 to avoid injury of neurovascular bundle) or by thoracoscope.

Statistics: Statistical presentation and analysis of the present study was conducted by IBM $\odot$ SPSS $\odot$ Statistics version 22 (IBM@ Corp., Armonk, NY, USA) and MedCalc (C) version 13 (MedCalc $@$ Software bvba, Ostend, Belgium). Normally distributed numerical variables presented as mean and SD and intergroup differences were compared by the unpaired $t$-test. The Welch test was used in place of the $t$-test when equality of variance of the two groups could not be assumed. Skewed data presented as median and interquartile range and differences compared by the MannWhitney test (for two-group comparisons) or the Kruskal-Wallis test (for multiple-group comparisons). Categorical data were presented as ratio or number and intergroup differences were compared by the Pearson chi-squared test. Receiver-operating characteristic (ROC) curve analysis was used to examine the value of ADA and other biomarkers in pleural aspirate. The DeLong method used to compare the area under ROC curves (AUC). And when $p$-value $<0.05$ was considered statistically significant.

\section{Diagnostic criteria:}

1-Patient considered a case of tuberculous effusion if any one of the following present histopathology showing Caseating granuloma or positive sputum culture for M.tuberculosis without other cause for exudative pleural effusion.

2- Patient considered with malignant pleural effusion when malignant tissue in the pleural cavity was shown by pleural biopsy or Cytopathology of the pleural fluid.

3- Parapneumonic effusion by clinical suspicion, laboratory diagnosis, culture and sensitivity for effusion.

\section{Results}

Forty patients included in the study twenty of them with tuberculous effusion and twenty with non tuberculous effusion as follows parapnemonic 5 cases and malignant effusion 15 cases (Table 2).

There is high statistical significant difference between groups in age. Tuberculous pleural effusion cases were younger than the other nontuberculous pleural effusion group ( $p 0.001$ high significant). Tuberculosis cases were younger than the other groups. (Malignant effusion versus Tuberculous effusion $p=0.001$ high significant). (Parapneumonic effusion versus Tuberculous effusion $p=0.001$ high significant). (Malignant effusion versus Para-pneumonic effusion $p=0.752$ nonsignificant) in (Table 3). Sex distribution among cases male 18 and female 22 in (Table 4). There is significant difference between groups in SGOT and SGPT. Cancer cases recorded the highest readings with $(p=0.008)(p=0.024)$ for both in (Table $5)$.

There is high significant difference between two groups in ADA pleural fluid $(p=0.0001)$ also there was statistical significant difference between two groups in protein level of pleural fluid ( $p=$ 0.006) in (Tables 6,7)

There is statistically elevated Mean ADA level in pleural aspirate, IU/1 96.5 IU/1 in tuberculosis cases and 13.0 IU/l in parapneumonic cases and $48 \mathrm{IU} / \mathrm{l}$ in malignant cases with $p$-value $<0.001$ in (Table 8).

There was high statistical significant difference between two groups in ADA $(p<0.0001)$ tuberculous effusion cases recorded higher levels of ADA than the other groups. There was no difference between cases with cancer and pneumonia in ADA. And low significant difference in protein $(p=0.001)$ between two groups in (Table 8).

ROC (Receiver Operating Characteristic) curve was used to obtain the cut-off points and the likelihood ratios (LRs) of ADA and show the cut-off value at $>68.8$ IU/l for diagnosis of cases with tuberculous pleural effusion (Table 9).

There was statistical significant difference between ADA cases Versus LDH in diagnosis of tuberculus effusion in (Table 10).

\section{Discussion}

Pleural effusion is the presence of fluid in the pleural space and categorized as either transudate or exudate [1]. And the exudative pleural effusions 
Table (1): Characteristics of the whole study population.

\begin{tabular}{ll}
\hline Variable & Metric \\
\hline Age, yr & $42.0(15.0)$ \\
Gender, M/F & $18 / 22$ \\
Smokers, $\mathrm{n}(\%)$ & $16(40 \%)$ \\
Fasting blood sugar, mg/dl & $96.5(88.0-116.5)$ \\
Blood urea nitrogen, mg/dl & $29.7(10.1)$ \\
Serum creatinine, mg/dl & $0.82(0.17)$ \\
SGOT, IU/1 & $14.5(9.0-23.0)$ \\
SGPT, IU/l & $14.5(9.0-21.5)$ \\
Total serum bilirubin, mg/dl & $0.71(0.11)$ \\
LDH level in pleural aspirate, IU/1 & $562.5(476.5-683.5)$ \\
Protein level in pleural & $4.2(3.8-4.9)$ \\
aspirate, mg/dl & \\
ADA level in pleural aspirate, IU/1 & $69.9(31.1-96.5)$ \\
\hline
\end{tabular}

Data presented as mean (SD), ratio, number or median (interquartile range).

Table (3): Age distribution among the study group.

\begin{tabular}{|c|c|c|c|c|}
\hline \multirow[t]{2}{*}{ Variable } & \multicolumn{2}{|c|}{$\begin{array}{l}\text { Non-tuberculous } \\
\text { pleural effusion } \\
\qquad(\mathrm{n}=20)\end{array}$} & \multirow{2}{*}{$\begin{array}{c}\text { Tuberculous } \\
\text { pleural } \\
\text { effusion } \\
(n=20)\end{array}$} & \multirow{2}{*}{$\begin{array}{c}p- \\
\text { value }\end{array}$} \\
\hline & $\begin{array}{l}\text { Malignant } \\
\text { effusion }\end{array}$ & $\begin{array}{c}\text { Para- } \\
\text { pneumonic } \\
\text { effusion }\end{array}$ & & \\
\hline & $52.73 \pm 9.41$ & $45.4 \pm 10.78$ & $30.85 \pm 10.49$ & $<0.0019$ \\
\hline Age, yr & \multicolumn{2}{|c|}{$53.2 \pm 9.5$} & $30.8 \pm 10.4$ & $<0.001$ \\
\hline
\end{tabular}

Table (2): Distribution of cases in the study groups

\begin{tabular}{|c|c|c|c|}
\hline \multicolumn{4}{|c|}{ Distribution of cases in the study groups } \\
\hline Tuberculous effusion & $20(50 \%)$ & & \\
\hline Non tuberculous effusi & & & \\
\hline Para-pneumonic & $5(12.5 \%)$ & & \\
\hline Malignant effusion: & & & \\
\hline $\begin{array}{l}\text { Metastatic } \\
\text { adenocarcinoma }\end{array}$ & $4(10 \%)$ & 15 & 20 \\
\hline $\begin{array}{l}\text { Epithelial } \\
\text { mesothelioma }\end{array}$ & $11(27.5 \%)$ & $(5 /, 5 \%)$ & $(50 \%)$ \\
\hline
\end{tabular}

Data presented as mean (SD), ratio, number, or median (interquartile range).

Table (4): Sex distribution among the study group.

\begin{tabular}{lccccc}
\hline Variable & $\begin{array}{c}\text { Non-tuberculous } \\
\text { pleural effusion } \\
(\mathrm{n}=20)\end{array}$ & $\begin{array}{c}\text { Tuberculous pleural } \\
\text { effusion } \\
(\mathrm{n}=20)\end{array}$ & $\begin{array}{c}p^{-} \\
\text {value }\end{array}$ \\
\hline Male & 8 & $40 \%$ & 10 & $50 \%$ & \\
Female & 12 & $60 \%$ & 10 & $50 \%$ & $0.525 \S$ \\
\hline
\end{tabular}

Data are presented as mean (SD), ratio, or number (\%),

qUnpaired $t$-test and §Pearson chi-squared test.

Table (5): Laboratory results of patients with tuberculous or non-tuberculous pleural effusion.

\begin{tabular}{|c|c|c|c|}
\hline Variable & $\begin{array}{l}\text { Non-tuberculouspleural } \\
\text { effusion } \\
(\mathrm{n}=20)\end{array}$ & $\begin{array}{l}\text { Tuberculous pleural } \\
\text { effusion } \\
(\mathrm{n}=20)\end{array}$ & $\begin{array}{c}p- \\
\text { value }\end{array}$ \\
\hline $\begin{array}{l}\text { Fasting blood } \\
\text { sugar, mg/dl }\end{array}$ & $108.5(90.0-121.0)$ & $92.0(85.5-107.0)$ & $0.088 \rrbracket$ \\
\hline $\begin{array}{l}\text { Blood urea } \\
\text { nitrogen, } \mathrm{mg} / \mathrm{dl}\end{array}$ & $32.1(13.0)$ & $27.4(5.1)$ & $0.142 \S$ \\
\hline $\begin{array}{l}\text { Serum creatinine, } \\
\mathrm{mg} / \mathrm{dl}\end{array}$ & $0.82(0.20)$ & $0.81(0.13)$ & $0.912 ¥$ \\
\hline $\begin{array}{l}\text { SGOT, IU/1 } \\
\text { SGPT, IU/1 }\end{array}$ & $\begin{array}{l}17.5(12.5-29.0) \\
17.5(12.0-28.0)\end{array}$ & $\begin{array}{l}9.0(8.0-18.0) \\
10.0(8.0-16.5)\end{array}$ & $\begin{array}{l}0.008 \text { व } \\
0.024 \text { 甲 }\end{array}$ \\
\hline $\begin{array}{l}\text { Total serum } \\
\text { bilirubin, } \mathrm{mg} / \mathrm{dl}\end{array}$ & $0.71(0.12)$ & $0.72(0.11)$ & $0.781 \#$ \\
\hline
\end{tabular}

Data are presented as median (interquartile range) or mean (SD), ๆMann-Whitney test, §Welch test,

Unpaired $t$-test, Unpaired $t$-test.

Table (6): Result of analysis of pleural fluid obtained from patients with tuberculous or nontuberculous pleural effusion.

\begin{tabular}{llll}
\hline Variable & \multicolumn{1}{c}{$\begin{array}{c}\text { Non-tuberculouspleural } \\
\text { effusion } \\
(\mathrm{n}=20)\end{array}$} & $\begin{array}{c}\text { Tuberculous pleural } \\
\text { effusion } \\
(\mathrm{n}=20)\end{array}$ & $\begin{array}{c}p \text { - } \\
\text { value }\end{array}$ \\
\hline LDH level in pleural aspirate, IU/1 & $544.0(428.0-696.5)$ & $562.0(490.0-666.0)$ & 0.6959 \\
Protein level in pleural aspirate, $\mathrm{mg} / \mathrm{dl}$ & $3.9(3.4-4.3)$ & $4.7(3.9-5.1)$ & 0.006 ฯ \\
ADA level in pleural aspirate, IU/1 & $44.1(21.68-59.5)$ & $96.5(88.3-135.0)$ & $<0.00019$ \\
\hline
\end{tabular}

Data are presented as median (interquartile range), $\uparrow$ Mann-Whitney test. 
Table (7): Result of analysis of pleural fluid obtained from patients with tuberculous effusion, Parapneumonic, metastatic adenocarcinoma, or mesothelioma.

\begin{tabular}{|c|c|c|c|c|c|}
\hline \multirow[b]{2}{*}{ Variable } & \multirow{2}{*}{$\begin{array}{l}\text { Non-tuberculous } \\
\text { pleural effusion } \\
\qquad(n=20)\end{array}$} & \multicolumn{3}{|c|}{ Tuberculous pleural effusion $(n=20)$} & \multirow{2}{*}{$\begin{array}{c}p- \\
\text { value }\end{array}$} \\
\hline & & $\begin{array}{l}\text { Pneumonia } \\
(n=5)\end{array}$ & $\begin{array}{c}\text { Metastatic } \\
\text { effusion }(n=4)\end{array}$ & $\begin{array}{l}\text { Mesothelioma } \\
\qquad(\mathrm{n}=11)\end{array}$ & \\
\hline $\begin{array}{l}\text { LDH level in } \\
\text { pleural aspirate, } \\
\text { IU/l }\end{array}$ & $\begin{array}{l}562.5 \\
(490.0-666.0)\end{array}$ & $\begin{array}{l}650.0 \\
(551.5-674.3)\end{array}$ & $\begin{array}{l}603.0 \\
(426.5-789.0)\end{array}$ & $\begin{array}{l}510.0 \\
(424.0-864.5)\end{array}$ & $0.842 \rrbracket$ \\
\hline $\begin{array}{l}\text { Protein level in } \\
\text { pleural aspirate, } \\
\text { mg/dl }\end{array}$ & $\begin{array}{l}4.7 \\
(3.9-5.1) \dagger+\end{array}$ & $\begin{array}{l}3.2 \\
(3.1-3.7)\end{array}$ & $\begin{array}{l}3.7 \\
(3.3-4.1)\end{array}$ & $\begin{array}{l}4.2 \\
(3.8-4.5) \dagger\end{array}$ & $0.003 \pi$ \\
\hline $\begin{array}{l}\text { ADA level in } \\
\text { pleural aspirate, } \\
\text { IU/l }\end{array}$ & $\begin{array}{l}96.5 \\
(88.3-135.0) \dagger+\S\end{array}$ & $\begin{array}{l}13.0 \\
(10.3-75.0)\end{array}$ & $\begin{array}{l}21.68 \\
(17.0-25.4)\end{array}$ & $\begin{array}{l}55.0 \\
(42.2-60.3)\end{array}$ & $<0.001 \rrbracket$ \\
\hline
\end{tabular}

Table (8): Result of analysis of pleural fluid obtained from patients with tuberculous, Parapneumonic, or malignant effusion including both (metastatic adenocarcinoma and mesothiloma).

\begin{tabular}{|c|c|c|c|c|}
\hline \multirow{2}{*}{ Variable } & \multirow[b]{2}{*}{$\begin{array}{c}\text { Tuberculous } \\
\text { effusion }(n=20)\end{array}$} & \multicolumn{2}{|c|}{ Non-tuberculous pleural effusion $(n=20)$} & \multirow{2}{*}{$\begin{array}{c}p- \\
\text { value }\end{array}$} \\
\hline & & $\begin{array}{l}\text { Para-pneumonic } \\
\text { effusion }(n=5)\end{array}$ & $\begin{array}{c}\text { Malignant } \\
\text { effusion }(n=15)\end{array}$ & \\
\hline $\begin{array}{l}\text { LDH level in } \\
\text { pleural aspirate, } \\
\text { IU/1 }\end{array}$ & $\begin{array}{l}562.5 \\
(490.0-666.0)\end{array}$ & $\begin{array}{l}650 . \\
(551.5-674.3)\end{array}$ & $\begin{array}{l}510.0 \\
(424.0-831.3)\end{array}$ & 0.718 \\
\hline $\begin{array}{l}\text { Protein level in } \\
\text { pleural aspirate, } \\
\mathrm{mg} / \mathrm{dl}\end{array}$ & $\begin{array}{l}4.7 \\
(3.9-5.1) \dagger \ddagger\end{array}$ & $\begin{array}{l}3.2 \\
(3.1-3.7)\end{array}$ & $\begin{array}{l}4.0 \\
(3.7-4.3) \dagger\end{array}$ & $0.002 \rrbracket$ \\
\hline $\begin{array}{l}\text { ADA level in } \\
\text { pleural aspirate, } \\
\text { IU/l }\end{array}$ & $\begin{array}{l}96.5 \\
(88.3-135.0) \dagger \dagger \S\end{array}$ & $\begin{array}{l}13.0 \\
(10.3-75.0)\end{array}$ & $\begin{array}{l}48.0 \\
(27.2-57.5)\end{array}$ & $<0.001$ \\
\hline
\end{tabular}

Table (9): Receiver-operating characteristic (ROC) curve analysis for the diagnosis of tuberculous pleural effusion using $\mathrm{ADA}, \mathrm{LDH}$, or protein level in pleural aspirate.

\begin{tabular}{llll}
\hline ROC curve parameter & ADA & LDH & Protein \\
\hline Area under the ROC curve (AUC) & 0.895 & 0.536 & 0.755 \\
$95 \%$ CI for AUC & 0.764 to 1.000 & 0.348 to 0.724 & 0.598 to 0.912 \\
$p$-value (AUC0=0.5) & $<0.0001$ & 0.705 & 0.001 \\
Youden index J & 0.8 & 0.25 & 0.45 \\
Best cutoff criterion & $>68.8 \mathrm{IU} / 1$ & $>436 \mathrm{IU} / 1$ & $>4.5 \mathrm{mg} / \mathrm{dl}$ \\
Sensitivity, \% & 90 & 95 & 55 \\
$95 \%$ CI for sensitivity & $68.3-98.8$ & $75.1-99.9$ & $31.5-76.9$ \\
Specificity, \% & 90 & 30 & 90 \\
$95 \%$ CI for specificity & $68.3-98.8$ & $11.9-54.3$ & $68.3-98.8$ \\
PPV, \% & 90 & 57.6 & 84.6 \\
$95 \%$ CI for PPV & $68.3-98.8$ & $39.2-74.5$ & $54.6-98.1$ \\
NPV, \% & 90 & 85.7 & 66.7 \\
$95 \%$ CI for NPV & $68.3-98.8$ & $42.1-99.6$ & $46.0-83.5$ \\
\hline PPV:Positive predive valu
\end{tabular}

PPV:Positive predictive value,

NPV: Negative predictive value. 
Table (10): Comparison of the receiver-operating characteristic (ROC) curves for the diagnosis of tuberculous pleural effusion using $\mathrm{ADA}, \mathrm{LDH}$, or protein level in pleural aspirate.

\begin{tabular}{lccc}
\hline Comparison & $\Delta \Delta \mathrm{AUC}$ & $\begin{array}{c}95 \% \text { CI for } \\
\Delta \Delta \mathrm{AUC}\end{array}$ & $\begin{array}{c}p \text { - } \\
\text { value }\end{array}$ \\
\hline ADA vs. protein & 0.140 & -0.053 to 0.333 & 0.154 \\
ADA vs. LDH & 0.359 & 0.117 to 0.601 & 0.004 \\
Protein vs. LDH & 0.219 & -0.018 to 0.456 & 0.071 \\
\hline \hline
\end{tabular}

$\triangle \triangle \mathrm{AUC}$ : difference between areas under the ROC curve.

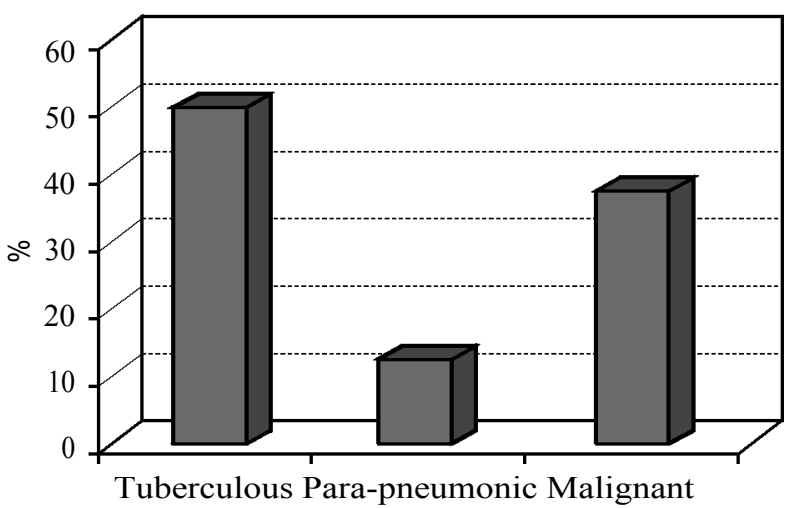

Histogram (1): Distribution of cases in the study groups.

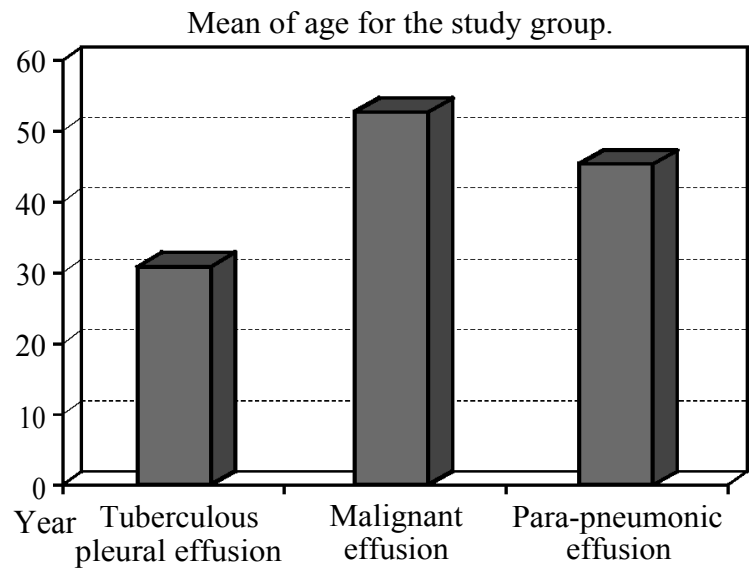

Histogram (2): Age distribution among the study group.

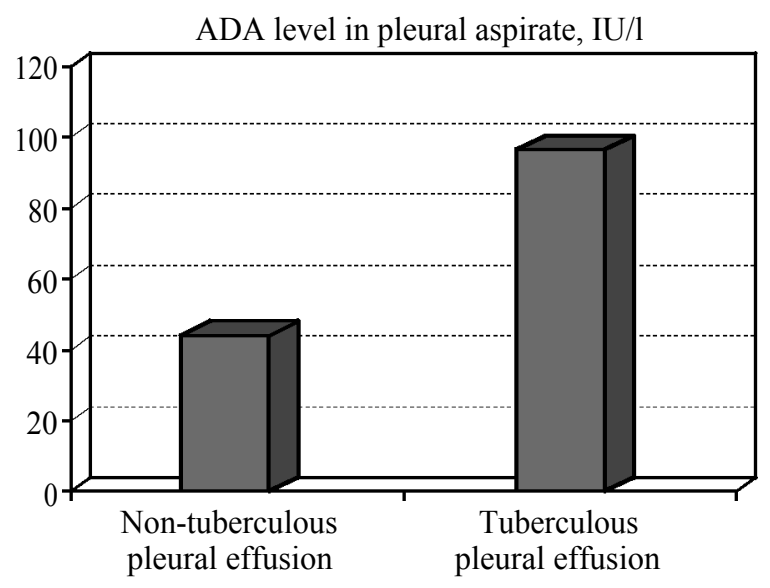

Histogram (3): ADA level in pleural aspirate, IU/1.

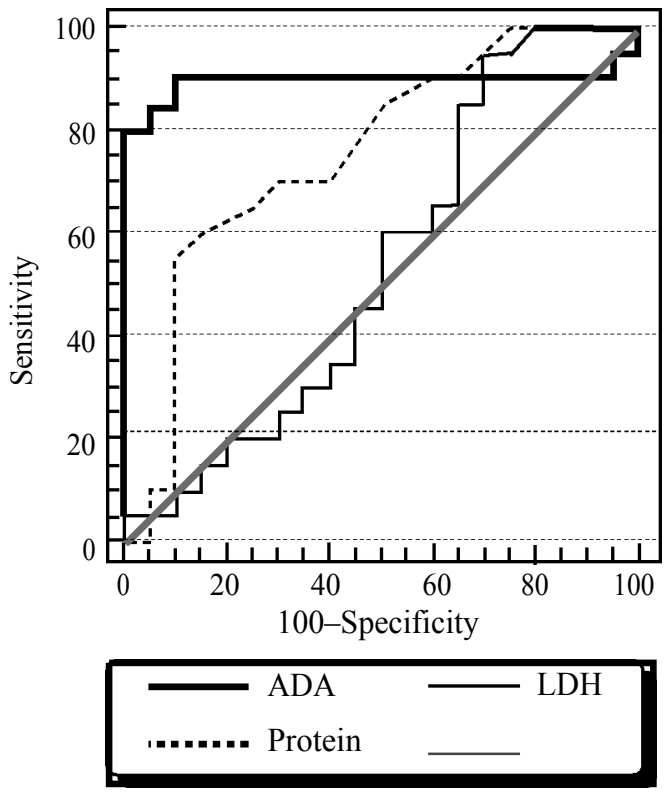

Histogram (4): Receiver-operating characteristic (ROC) curves for the diagnosis of tuberculous pleural effusion using ADA, LDH, or protein level in pleural fluid.

are serious and difficult to treat. So there is a need for simpler test to help in diagnosis of pleural effusion [6]. There is a long list of causes including: Infection (Para pneumonic) with its causative organisms (bacterial, viral, parasitic), malignancy (pleural tumors, metastatic effusion), pulmonary embolism, abdominal diseases (sub phrenic abscess hepatic amebiasis), collagen vascular diseases (SLE, rheumatoid arthritis) and others (drugs, sarcoidosis, asbestosis [7].

And aim of this study is to assess role of adenosine deaminase enzyme level in pleural fluid to differentiate between cases with tuberculous pleural effusion and cases with non tuberculous pleural effusion.

This study was carried out on (40) patients, selected from chest department in Al-Hussein University Hospital, Bab El-Sha'eria university Hospital and \& Giza chest hospital after recording written consent from the patients during period between April 2014 and May 2016.

In the present study there 40 patients with mean age $30.8 \pm 10.4$ years for tuberculous pleural effusion, $53.2 \pm 9.5$ years for non tuberculous pleural effusion including $45.4 \pm 10.78$ years for Parapneumonic pleural effusion and $52.73 \pm 9.41$ years for malignant pleural effusion in Table 3 this shows tuberculous pleural effusion common in young age and malignant pleural effusion present in mean 
age 52,7 years and his in agreement with Valdes et al study who found that the mean age of tuberculous group was $33.9 \pm 13.2$ years and that of malignant group was $45.5 \pm 16.8$ years [8] .

In the present study there is 18 patients were male and 22 were female, 10 male, 10 female in tuberculous effusion group, 8 male and 12 female in non tuberculous effusion group with no statistical significance in Table (4).

There is elevation in median level of LDH in tuberculous pleural effusion 562 IU/1 less than Para-pneumonic effusion 650 IU/l, Metastatic effusion $603.0 \mathrm{IU} / \mathrm{l}$ without statistical significance (Table 8).

There is elevation in median level of protein in tuberculous pleural effusion $4.7 \mathrm{mg} / \mathrm{dl}$ than the median level of protein in Para-pneumonic, metastatic effusion and pleural effusion due to mesothelioma with statistical significance and $p$-value 0.003 (Tables 7,8).

There is elevation in median level of ADA in tuberculous pleural effusion $96.5 \mathrm{IU} / 1$ than the median level of ADA in Para-pneumonic, metastatic effusion and pleural effusion due to mesothelioma with statistical significance $p$-value $<0.001$ Tables $(7,8)$. These results agree with values obtained by Petterson $t$ et al study who reported that the ADA activity increases in tuberculous pleural effusion in average 90 and 100 IU/I [9] .

These results are in agreement with the results obtained by Mohd et al., who found that protein concentration in pleural fluid of more than $5 \mathrm{gm} / \mathrm{dl}$ was seen in $64 \%$ and found that elevated lactic acid dehydrogenase (LDH) of more than $400 \mathrm{U} / \mathrm{L}$ was seen in $77 \%$ patients with pleural fluid TB [10].

In the present study the Best cutoff criterion for ADA > 68.8 IU/l is highly suggestive to tuberculous pleural effusion with sensitivity $90 \%$, specificity $90 \%$, positive predictive value $90 \%$ and negative predictive value $90 \%$ with Area under the ROC curve AUC 0.895 and $p$-value $<0.0001$ (Table 9).

These results are in agreement with results obtained by Orphanidou et al., study who reported that sensitivity (87.3\%) and specificity $(91.8 \%)$ [11] and also are in agreement with Banales et al., study they reported sensitivity was found as $98 \%$, specificity $96 \%$, PPV $94 \%$ and NPV $99 \%$ for the cutoff value of ADA $70 \mathrm{U} / \mathrm{L}$ with a mean \pm SD
123.25 \pm 39.4 [12] and with Reechaipichitkul et al., study who found sensitivity $98 \%$, specificity $96 \%$, PPV $94 \%$ and NPV $99 \%$ for the cutoff value of ADA $70 \mathrm{U} / \mathrm{L}$ with a mean \pm SD $123.2 \pm 39.4$ [13] and with Jimenez et al., study who reported that elevated pleural fluid ADA level predicts tuberculous pleural effusions with a sensitivity of $90 \%$ and a specificity of $89 \%$. They reported cutoff value for ADA varies from 47 to $60 \mathrm{UI} / \mathrm{L}$ [14]

Perez-Rodriguez, et al., found that pleural fluid ADA activity has a valuable biochemical marker that has a high sensitivity and specificity for pleural tuberculosis diagnosis [15].

In a review study by Krenke and Korczyn'ski on adenosine deaminase and interferon gamma in diagnosis of pleural effusion, they found an important role for both in diagnosis of tuberculous pleurisy [16].

\section{Conclusion:}

Patients with tuberculous pleural effusion had higher ADA level in pleural fluid than patients with non-tuberculous effusion (para-pneuomonic and malignant effusion) $p<0.001$ ) with cutoff point was $68.8 \mathrm{IU} / \mathrm{l}$, with sensitivity and specificity were $90 \%$ and positive predictive value was $90 \%$.

\section{References}

1- LIGHT RW.: Clinical practice. Pleural effusion. N. Engl. J. Med., 346: 347, 2002.

2- SU S.B., QIN S.Y., GUO X.Y., LUO W. and JIANG H.X.: As-sessment by meta-analysis of interferon-gam-ma for the diagnosis of tuberculous peritonitis. World. J. Gastroenterology, 19: 1645-51, 2013.

3- TAY T.R. and TEE A.: Factors affecting pleural fluid adenosine deaminase level and the implica-tion on the diagnosis of tuberculous pleural ef-fusion: A retrospective cohort study. BMC In-fect Dis., 13: 546, 2013.

4- MARTÍNEZ M.A., CASES E. and CORDERO P.J.: Diagnostic utility of eosinophils in the pleural fluid. Eur. Respir. J., Vol. 15 pp. 166-169, 2000.

5- XUWEI G. and HEPING X.: Review Article, Diagnosis of tuberculosis pleurisy with adenosine deaminase (ADA): a systematic review and meta-analysis. Int. J. Clin. Exp. Med., 7 (10): 3126-35, 2014.

6- EFRATI O. and BARAK A.: Pleural effusions in the pediatric population. Pediatr Rev. Dec, 23 (12): 417-26, 2002.

7- LIGHT R.W.: Anatomy of pleura and Pleural diseases. $4^{\text {th }}$ edition, Philadelphia; Lippincott Williams and Wilkins, Richard W. Light, 2001.

8- VALDÉS L., SAN JOSÉ M.E. and POSE A.: Diagnosing tuberculous pleural effusion using clinical data and pleural fluid analysis: A study of patients less than 40 years-old 
in an area with a high incidence of tuberculosis. Respir. Med. Aug., 104 (8): pp. 1211-7, 2010.

9- PETTERSON T., OJALA K. and WEBER T.: Adenosine deaminase in the diagnosis of pleural effusions. Acta. Med. Scand., 215 (4): 299-04, 1984.

10- MOHD A., FAROOQ A., BASHIR A., SHABIR A., MOHD L., NASIR-U and MASARATUL G.: The Diagnostic Efficacy of Adenosine Deaminase in Tubercular Effusion. Oman. Med. J. Nov., 28 (6): 417-21, 2013.

1 1- ORPHANIDOU D., STRAKOS G., RASIDAKIS A., TOUMBIS M., BAKAKOS P., SAMARA J., et al.: Adenosine deaminase activity and lysozyme levels in Bronchoalveolar lavage fluid in patient T.B. Int. J. tuberc. lung. Dis., 2 (2): 147-52, 1998.

12- BANALES J.L., PINEDA P.R., FITZGERALD J.M., RUBIO H, SELMAN M. and SALAZAR M.: Adenosine deaminase in the diagnosis of tuberculous pleural effusions.
A report of 218 patients and review of the literature. Chest Feb., 99 (2): 355-7, 1991.

13- REECHAIPICHITKUL W., KAWAMATAWONG T. TEERAJETGUL Y. and PATJANASOONTORN B.: Diagnostic role of pleural fluid adenosine deaminase in tuberculous pleural effusion. Southeast Asian. J. Trop. Med. Public Health, Jun., 32 (2): 383-9, 2001.

14- JIMENEZ D., DIAZ G., BAND E. and PEREZ-R.: Diagnosis of pleural tuberculosis. Chest Mar., 121: 1005-15, 2002.

15- PEREZ E., PEREZ I.J., SANCHEZ J., PALLARES E., RUBI J., JIMENEZ D., DIAZ G.: ADA1/ADAp ratio in pleural tuberculosis an excellent diagnostic parameter in pleural fluid. Respir Med. Nov., 93 (11): 816-21, 1999.

16- KRENKE R. and KORCZYN'SKI P.: Use of pleural fluid levels of adenosine deaminase and interferon gamma in the diagnosis of tuberculous pleuritis. Curr. Opin. Pulm. Med. Jul., 16 (4): 367-75, 2010.

\section{تقييم القيمة التشخيصية للأدينوزين دى أمينيز فى تشخيص الانصباب البلورى السلى لادينى}

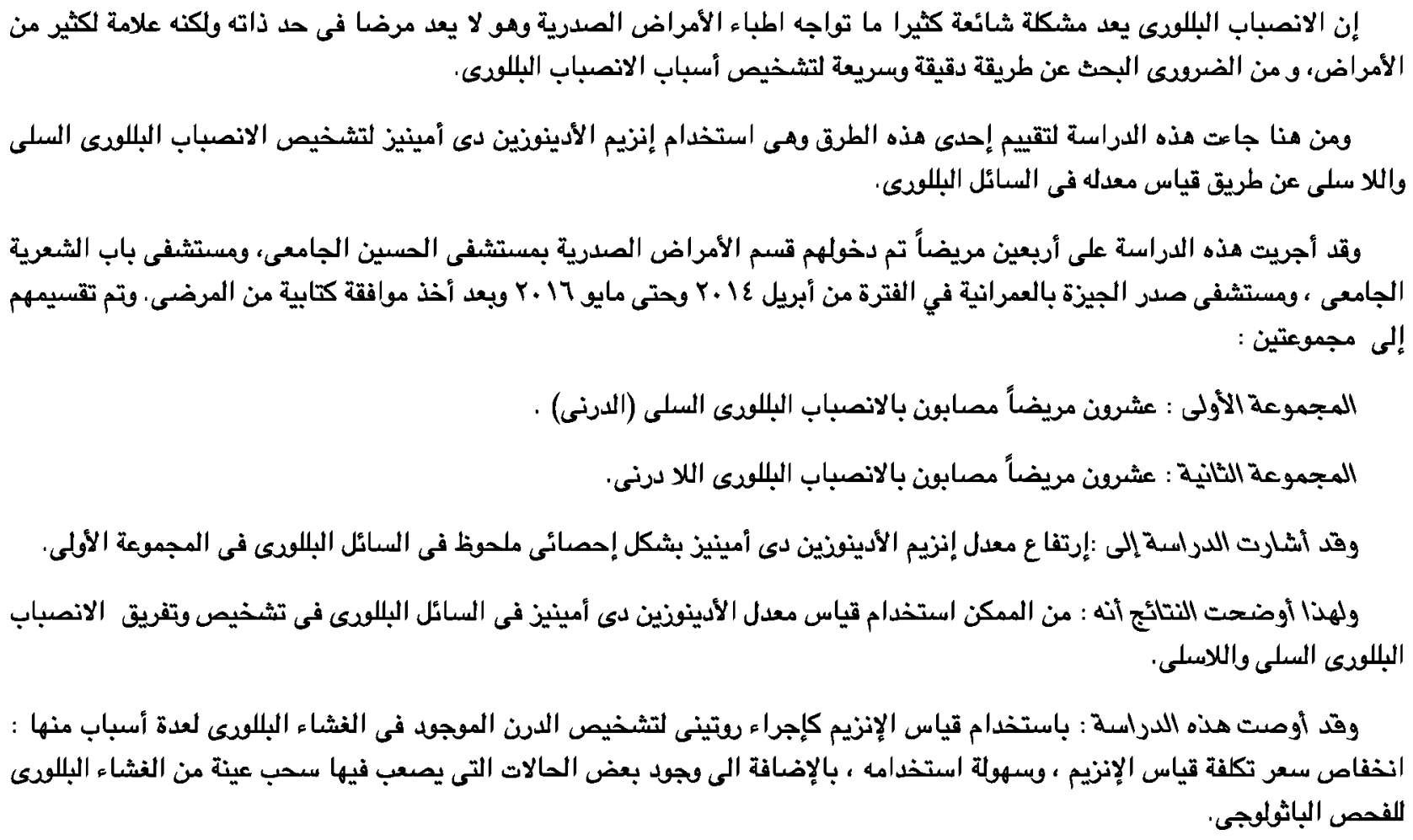

